\title{
Evaluation of argyrophilic nucleolar organiser regions (AgNORs) in multiple myeloma
}

\author{
S I Papadhimitriou, D Daskalopoulou, P Tsaftaridis, S Markidou, M Stamatelou
}

\begin{abstract}
Aim-To investigate the prognostic value of argyrophylic nucleolar organiser regions (AgNORs) in multiple myeloma. Methods-Bone marrow aspirates from 55 newly diagnosed patients with multiple myeloma were stained with the one step $\mathrm{AgNO}_{3}$ technique. The mean number of AgNORs in each plasma cell nucleus (AgNOR count) was tested for a possible correlation with other clinical and laboratory variables at presentation (clinical stage, substage, heavy and light chain isotype, haemoglobin concentration, platelet count, marrow infiltration rate, degree of skeletal lesions, $M$ protein concentration, plasma cell morphology, and serum concentrations of calcium, albumin, lactate dehydrogenase, $C$ reactive protein, and $\beta_{2}$ microglobulin) and with outcome (response to first line treatment, first remission duration, and overall survival).

Results-A significant association between mean (SD) AgNOR count was found only for clinical stage (stage I, 3.09 (1.19); stage II, 3.80 (1.53); stage III, 5.28 (1.79); $p<0.005)$ and, from all stage determinants, only for $M$ protein concentration (high, 5.92 (1.80); low, 4.01 (1.92); $\mathbf{p}<0.001)$. There was a linear relation between AgNOR count and serum $M$ protein concentration for patients with both IgG $(r=0.450 ; \quad \mathbf{p}<0.01)$ and IgA $(r=0.768 ; \mathbf{p}<0.002)$ producing multiple myeloma.

Conclusions-Unlike previous investigations, no clear prognostic value for the AgNOR count was found in multiple myeloma. Instead, the results indicate that the AgNOR count might be an index for $M$ protein synthesis rate. This is consistent with other findings in tissues with low proliferative potential and high protein synthetic activity, and calls for a cautious interpretation of AgNORs in malignancies with similar features. (F Clin Pathol 2000;53:462-465)
\end{abstract}

Keywords: argyrophilic nucleolar organiser regions, multiple myeloma; $M$ protein synthesis; prognosis

Nucleolar organiser regions (NORs) are DNA sequences on the short arms of acrocentric chromosomes, which encode ribosomal RNA. ${ }^{1}$ Owing to their argyrophilic nucleoproteins, silver stained NORs (AgNORs) can be visualised in routine histological or cytological preparations as black or dark brown dots in the interphase nucleus. ${ }^{2}$ AgNOR frequency is considered to be an index of transcriptional activity and hence a measure of the cellular mitotic potential. ${ }^{3}$ The mean number of AgNORs in each nucleus (AgNOR count) is now widely used in tumour pathology as a diagnostic and prognostic marker, ${ }^{4-6}$ because it can discriminate between malignant and benign or reactive proliferations, and has been shown to correlate well with the degree of aggressiveness and patient survival in many different cancers, including haematological malignancies. ${ }^{7-10}$

Multiple myeloma is a neoplasia of the B lymphocytic lineage characterised by lytic bone lesions, proliferation of plasma cells in the bone marrow and extramedullary sites, and high concentrations of a monoclonal immunoglobulin ( $M$ protein). Although the disease is currently incurable, there is considerable variation in outcome, with some patients dying within a few months from diagnosis, whereas others survive for up to a decade, or even longer. Despite intensive efforts, the prognostic markers investigated so far have failed consistently to identify patients at a higher risk, who would benefit from a more aggressive therapeutic intervention, or those with a slower progression, in whom a gentle initial approach is appropriate. Therefore the continuing search for parameters with a higher prognostic value is mandatory. ${ }^{11}$

In this retrospective study, we have investigated the prognostic value of the AgNOR count in multiple myeloma by estimating the mean number of AgNORs in each plasma cell in bone marrow smears at diagnosis, and testing for a possible association with major clinical and laboratory variables and with outcome.

\section{Materials and methods}

PATIENTS AND DATA

Our study comprised 55 patients with multiple myeloma (37 men, 18 women), with a mean (SD) age of 59.9 (11.1) years (median, 61; range, 28-86). The diagnosis was based on the criteria of the chronic leukaemia-myeloma task force, ${ }^{12}$ thus excluding cases of "smouldering" myeloma. All patients were initially treated with melphalan and prednisone, or the VAD regimen (vincristine, doxorubicin, and dexamethasone intravenously every four weeks), and those achieving partial or complete remission were given $\alpha$ interferon as maintenance until relapse. Clinical stage and substage (Durie-Salmon system), ${ }^{13}$ heavy and light chain isotype, scale of skeletal lesions, bone marrow infiltration rate, $M$ protein concentration, haemoglobin concentration, platelet count, serum albumin, calcium, and lactate dehydrogenase $(\mathrm{LDH})$ value, response to
Accepted for publication 11 November 1999 
Table 1 Association of argyrophilic nucleolar organiser region (AgNOR) count with clinical and biological parameters at diagnosis

\begin{tabular}{|c|c|c|c|c|}
\hline Parameter & $N$ & $\%$ & $\begin{array}{l}\text { AgNOR count } \\
\text { (mean (SD)) }\end{array}$ & Significance \\
\hline \multicolumn{5}{|l|}{ Stage } \\
\hline I & 8 & 14.5 & $3.09(1.19)$ & \multirow{3}{*}{$\mathrm{p}<0.005$} \\
\hline II & 9 & 16.4 & $3.80(1.53)$ & \\
\hline III & 38 & 69.1 & $5.28(1.79)$ & \\
\hline \multicolumn{5}{|l|}{ Substage } \\
\hline A & 48 & 87.3 & $4.73(1.93)$ & \multirow{2}{*}{ NS } \\
\hline $\mathrm{B}$ & 7 & 12.7 & $4.60(1.42)$ & \\
\hline \multicolumn{5}{|l|}{ Heavy chain isotype } \\
\hline$\gamma$ & 35 & 63.6 & $4.79(1.79)$ & \multirow[t]{5}{*}{ NS } \\
\hline$\alpha$ & 14 & 25.5 & $3.99(1.85)$ & \\
\hline$\delta$ & 1 & 1.8 & 7.3 & \\
\hline Bence-Jones & 4 & 7.3 & $6.38(1.55)$ & \\
\hline Non-secretory ${ }^{\star}$ & 1 & 1.8 & 3.2 & \\
\hline \multicolumn{5}{|l|}{ Light chain isotype } \\
\hline$\kappa$ & 32 & 58.2 & $4.89(1.87)$ & \multirow[t]{2}{*}{ NS } \\
\hline$\lambda$ & 23 & 41.8 & $4.50(1.87)$ & \\
\hline \multicolumn{5}{|c|}{ Haemoglobin $(\mathrm{g} / 1)$ (overall range, $68-160 ;$ median, 107 , mean, $110.7 ; \mathrm{SD}, 19.7$ ) } \\
\hline$\leqslant 105$ & 26 & 47.3 & $5.16(2.11)$ & \multirow[t]{2}{*}{ NS } \\
\hline$>105$ & 29 & 52.7 & $4.32(1.54)$ & \\
\hline \multicolumn{5}{|c|}{ Calcium (mg/1) (overall range, $78-127$; median, $99 ;$ mean, $98.5 ; \mathrm{SD}, 9.8$ ) } \\
\hline$\leqslant 100$ & 36 & 65.5 & $4.47(1.79)$ & \multirow[t]{2}{*}{ NS } \\
\hline$>100$ & 19 & 34.5 & $5.19(1.96)$ & \\
\hline \multicolumn{5}{|l|}{ Skeletal lesions scale } \\
\hline 0 & 9 & 16.4 & $3.91(1.89)$ & \multirow[t]{4}{*}{ NS } \\
\hline 1 & 4 & 7.3 & $4.48(1.72)$ & \\
\hline 2 & 14 & 25.4 & $4.76(1.95)$ & \\
\hline 3 & 28 & 50.9 & $4.99(1.86)$ & \\
\hline \multicolumn{5}{|c|}{ M protein concentration $\dagger$} \\
\hline Low & 34 & 64.2 & $4.01(1.52)$ & \multirow{2}{*}{$\mathrm{p}<0.001$} \\
\hline High & 19 & 35.8 & $5.92(1.80)$ & \\
\hline \multicolumn{5}{|c|}{ Platelet count $\left(\times 10^{9} / 1\right)$ (overall range, $75-340$; median, 200$) \mathrm{ff}$} \\
\hline$\leqslant 150$ & 11 & 20.0 & $4.67(1.46)$ & \multirow[t]{2}{*}{ NS } \\
\hline$>150$ & 44 & 80.0 & $4.73(1.97)$ & \\
\hline \multicolumn{5}{|c|}{ Albumin $(\mathrm{g} / \mathrm{l})$ (overall range, $21-48$; median, $35 ;$ mean, $34.9 ; \mathrm{SD}, 6.8$ ) } \\
\hline$\leqslant 30$ & 17 & 30.9 & $4.95(1.85)$ & \multirow[t]{2}{*}{ NS } \\
\hline$>30$ & 38 & 69.1 & $4.61(1.88)$ & \\
\hline $\mathrm{LDH}(\mathrm{U} / \mathrm{l})$ (overal & $4 ; \mathrm{me}$ & , 127) & & \\
\hline$\leqslant 180$ & 46 & 83.6 & $4.89(1.82)$ & NS \\
\hline$>180$ & 9 & 16.4 & $4.31(2.32)$ & \\
\hline Marrow infiltration & erall $\mathrm{r}$ & $15-9$ & dian, 50)ff & \\
\hline$\leqslant 30$ & 18 & 32.7 & $4.61(1.37)$ & NS \\
\hline $31-50$ & 15 & 27.3 & $3.81(1.69)$ & \\
\hline$>50$ & 22 & 40.0 & $5.42(2.10)$ & \\
\hline Histological grade & & & & \\
\hline I & 29 & 52.7 & $4.87(1.78)$ & NS \\
\hline II & 18 & 32.7 & $4.58(1.88)$ & \\
\hline III & 8 & 14.6 & $4.46(2.30)$ & \\
\hline$\beta_{2} \mathrm{~m}(\mathrm{mg} / \mathrm{l})$ (overall & $1.3 ; \mathrm{m}$ & $\mathrm{n}, 3.0)$ & & \\
\hline$\leqslant 6.0$ & 39 & 70.9 & $4.68(1.83)$ & NS \\
\hline$>6.0$ & 16 & 29.1 & $4.80(2.02)$ & \\
\hline CRP (mg/l) (overa & 17.0 & lian, 5 . & & \\
\hline$\leqslant 6.0$ & 30 & 54.5 & $4.39(1.92)$ & NS \\
\hline$>6.0$ & 25 & 45.5 & $5.10(1.75)$ & \\
\hline
\end{tabular}

^Cytoplasmic $\kappa$ chain only.

†Overall range (median): serum IgG, 18.5-90.1 g/1 (57.8); serum IgA, 10.5-61.8 g/1 (28.65); urinary light chain, 2.4-13.7 g/24 hours (9.4).

$\ddagger \mathrm{IgG}, \leqslant 60 \mathrm{~g} / 1 ; \mathrm{IgA}, \leqslant 40 \mathrm{~g} / 1$; urinary light chain $\leqslant 8 \mathrm{~g} / 24$ hours.

TTotal 53 (IgD and non-secretory patients not included).

ffMean (SD) are not given for distributions significantly deviating from normal.

$\beta_{2} \mathrm{~m}, \beta_{2}$ microglobulin; CRP, C reactive protein; $\mathrm{LDH}$, lactate dehydrogenase; NS, not significant.

initial treatment (according to the criteria adopted by the chronic leukaemia-myeloma task force), ${ }^{14}$ first remission duration, and overall survival were retrieved from the patients' files. $C$ reactive protein (CRP) and $\beta_{2}$ microglobulin concentrations were determined by immunonephelometry on serum samples stored at $-20^{\circ} \mathrm{C}$. Tables 1 and 2 show the distribution of these variables within the study population.

AgNOR STAINING AND ESTIMATION

Air dried bone marrow smears, obtained at diagnosis and subsequently stored at $-20^{\circ} \mathrm{C}$, were processed with the standard one step
$\mathrm{AgNO}_{3}$ stain (2\% gelatin, $1 \%$ formic acid, and $50 \% \mathrm{AgNO}_{3}$ for 12 minutes at $\left.37^{\circ} \mathrm{C}\right)^{15}$ and counterstained with haematoxylin (fig 1). Cytological preparations of breast adenocarcinoma were used as controls. Two slides for each patient were examined blindly by a cytologist under oil immersion (magnification $\times 100$ ). For the $\mathrm{AgNOR}$ enumeration, all silver precipitates within the nucleus were taken into account, and dots aggregated in clusters were counted as one AgNOR. ${ }^{16}$ For all cases, the AgNOR count was calculated as the average from a total of 200 plasma cells. The reproducibility of the counting method was tested in 30 randomly selected smears. Average intraobserver and interobserver variation was $0.56 \%$ and $2.43 \%$ (maximum $2.14 \%$ and $4.65 \%)$, respectively.

\section{PLASMA CELL MORPHOLOGY}

For the purposes of our study, plasma cell morphology was re-evaluated by a haematologist who examined May-Grunwald-Giemsa stained marrow aspirates under oil immersion (magnification $\times 100$ ). According to the predominant cell types in the plasmacytic infiltrate, cases were classified into three groups of histological grade, based on a classification system proposed by Bartl et $a l^{17}$ : grade I (Marschalko and small cells), grade II (small and polymorphous cells), and grade III (asynchronous plasma cells and plasmablasts).

\section{STATISTICS}

AgNOR count differences among groups were estimated with the student's $t$ test or the one way analysis of variance (ANOVA). The impact on remission duration and overall survival was assessed by the use of the Kaplan-Meier product limit estimates and the log rank test. The association between AgNOR count and other quantitative variables was tested on a linear regression model. Significance was set at $\mathrm{p}<0.05$ for all tests.

\section{Results}

The AgNOR count ranged from 1.2 to 9.1, with the median at 4.4 (mean, $4.72 ; \mathrm{SD}, 1.87$ ), and its distribution was essentially normal. With regard to parameters at presentation, there was a significant association with clinical stage (stage III $v$ stage I, $\mathrm{p}<0.001$; stage III $v$ stage II, p < 0.02) and with the concentration of $M$ protein (table 1 ). On linear regression analysis, there was a significant relation between serum concentration and AgNOR count for both $\operatorname{IgG}(\mathrm{n}=35 ; r=0.450 ; \mathrm{p}<0.01)$ and IgA cases $(\mathrm{n}=14 ; r=0.768 ; \mathrm{p}<0.002)$ (fig 2).

There was no signification association between AgNOR count and the outcome variables tested (table 2). Survival for patients with a lower count $(\leqslant 4.4)$ was shorter $(31.5 \vee 40$ months), but the difference did not reach significance (fig 3 ). Patients with very short (up to 6 months) or long survival (more than seven years) were evenly distributed between the two groups. 
Table 2 Association of argyrophilic nucleolar organiser region (AgNOR) count with outcome

\begin{tabular}{|c|c|c|c|c|}
\hline Parameter/Group & $N$ & $\%$ & Measure & Significance \\
\hline Response to first treatment & & & \multicolumn{2}{|c|}{ AgNOR count (mean (SD)) } \\
\hline Complete & 13 & 23.6 & $5.16(1.86)$ & \multirow[t]{3}{*}{ NS } \\
\hline Partial & 20 & 36.4 & $4.06(1.45)$ & \\
\hline NR or PD & 22 & 40.0 & $5.05(2.10)$ & \\
\hline First remission duration (months) ${ }^{*}$ & & & \multicolumn{2}{|c|}{ Remission duration (mean (range)) } \\
\hline AgNOR count $\leqslant 4.4$ & $17^{\star \star}$ & 51.5 & $10(2-116+)$ & \multirow[t]{2}{*}{ NS } \\
\hline $\mathrm{AgNOR}$ count $>4.4$ & 16 & 48.5 & $14.5(3-41)$ & \\
\hline Survival (months) $\dagger$ & & & \multicolumn{2}{|c|}{ Survival (median (range)) } \\
\hline AgNOR count $\leqslant 4.4$ & $29 \ddagger$ & 52.7 & $40(4-123)$ & NS \\
\hline AgNOR count $>4.4$ & $26^{\circ}$ & 47.3 & $31.5(4-102)$ & \\
\hline
\end{tabular}

${ }^{\star}$ First remission duration: overall range, $2-116+$; median, 10.

$\star \star$ Two censored observations (102 and 116 months).

†Survival: overall range, 4-123 months; median, 37.

† Two censored observations (108 and 122 months).

Two censored observations (99 and 102 months).

$\mathrm{NR}$, no response; NS, not significant; PD, progressive disease.

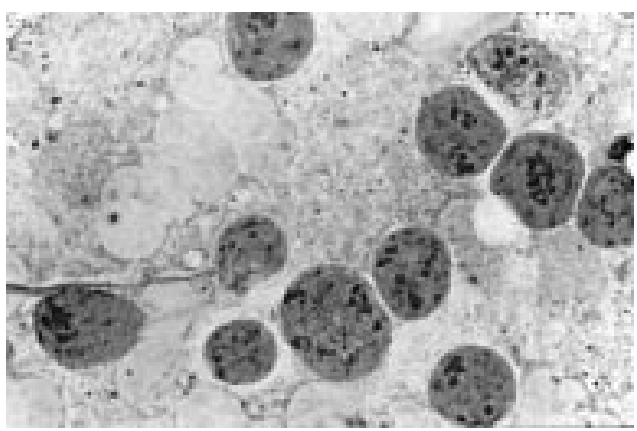

Figure $1 \mathrm{AgNO}_{3}$ stained bone marrow smear from a patient in our study (magnification, $\times 1000)$. Argyrophilic nucleolar organiser regions (AgNORs) are visible as dark dots within the plasma cell nuclei.

\section{Discussion}

According to previous studies, the mean number of AgNORs in each plasma cell in marrow biopsies is an independent prognostic factor in multiple myeloma. ${ }^{18} 19$ The AgNOR count has also been found to correlate well with plasma cell proliferative activity, measured by bromodeoxyuridine or proliferating cell nuclear antigen expression. ${ }^{20}{ }^{21}$ However, another study did not show any difference in AgNOR count between multiple myeloma and monoclonal gammopathy of undetermined importance, ${ }^{22}$ although it is known that the mitotic potential of the plasma cells is one of the most reliable differentiating features of the two conditions. ${ }^{23}$ Our data do not allow us to draw conclusions on the association between

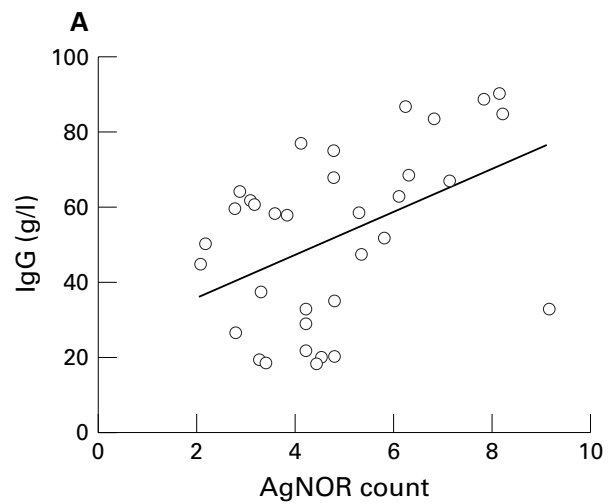

AgNOR count and proliferative activity in multiple myeloma, but we did not find a clear prognostic value for AgNOR enumeration in our study population. Nevertheless, it must be noted that, unlike investigators reaching a different conclusion, we examined aspirates instead of biopsies and applied a different counting protocol, scoring clusters as one AgNOR instead of trying to identify individual dots within aggregates. These methodological differences might have contributed to the discrepancy.

Alternatively, our results suggest that the AgNOR count might be an indicator of the protein synthetic activity of the plasma cells. The concentration of $M$ protein in multiple myeloma is determined by the number of plasma cells in the body, their synthetic activity, and the paraprotein catabolic rate. In vitro studies have shown that the M protein synthesis rate can vary considerably among patients, ranging from 2.5 to $35 \mathrm{pg} / \mathrm{cell} / \mathrm{day},{ }^{24}$ while an increase of the estimated tumour burden from $0.2 \times 10^{12}$ to just over $2 \times 10^{12}$ cells $/ \mathrm{m}^{2}$ can often make the difference between clinical detectability and death. ${ }^{25}$ On the contrary, the catabolic rate is constant for a given $M$ protein type. The two IgA subclasses have the same serum half life (six days), whereas the IgG3 subclass has a shorter half life compared with the other three IgG subclasses (eight instead of 23 days). ${ }^{26}$ This fact, together with the lower amount of residual polyclonal IgA in the serum of patients with multiple myeloma, might account for the closer association found in our series between the AgNOR count and $M$ protein concentration in the patients with IgA producing multiple myeloma.

Apart from their role in the control of the cell cycle, NORs are also the templates for the production of ribosomal subunits. In cells heavily engaged in protein synthesis, more NORs will probably be actively transcribed to maintain the great number of ribosomes needed for this process and, hence, more AgNORs will be cytologically demonstrable. ${ }^{45}$ The value of AgNOR quantification as an index of the protein synthesis rate has been confirmed in a few studies on benign tissues with limited or no mitotic potential. ${ }^{27}{ }^{28}$ In tumours with similar features, the interpretation of the AgNOR

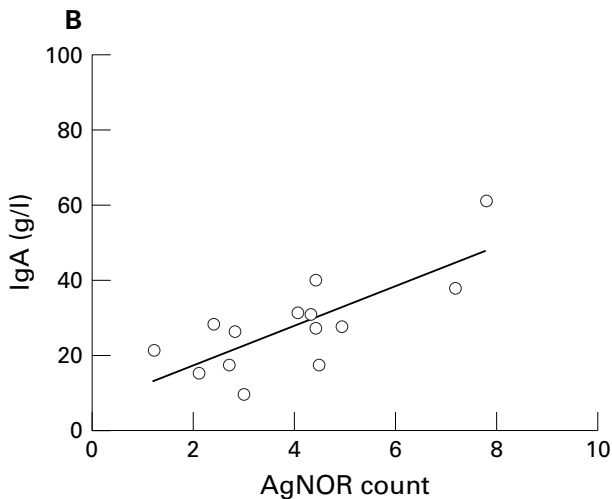

Figure 2 Correlation between serum $M$ protein concentration and argyrophilic nucleolar organiser region (AgNOR) count (dot diagram and best fitting line). (A) Patients with IgG producing multiple myeloma; (B) patients with IgA producing multiple myeloma. 


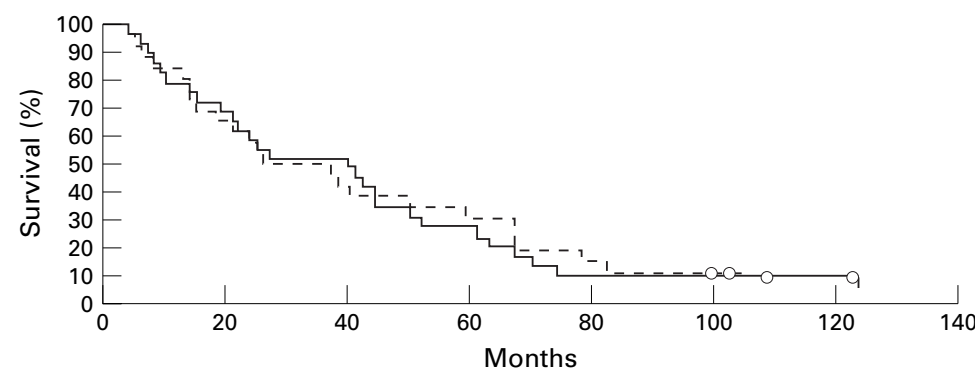

Figure 3 Kaplan-Meier curves for the survival of patients, grouped according to argyrophilic nucleolar organiser region (AgNOR) count. Solid line, AgNOR > 4.4; dotted line, $A g N O R \leq 4.4$. Circles represent censored observations.

count is obviously problematical. ${ }^{29}$ Multiple myeloma can be viewed as a unique example of such a neoplasm, ${ }^{30}$ because the proliferative activity of neoplastic plasma cells is in most cases very low compared with their enormous synthetic capacity. ${ }^{24} 31$ Carefully designed in vitro studies are needed to clarify which of these two cytophysiological attributes is best reflected in the AgNOR count.

1 Gall JG, Pardue ML. Formation and detection of RNADNA hybrid molecules in cytological preparation. Proc Natl Acad Sci US A 1969;63:378-83.

2 Ploton D, Menager M, Jeannesson P, et al. Improvement in the staining and in the visualization of the argyrophilic proteins of the nucleolar region at the optical level. Histochem $\mathcal{F}$ 1986;18:5-14.

3 Fakan S, Hernandez-Verdun D. The nucleolus and the nucleolar organizer regions. Biol Cell 1986;56:189-206.

4 Underwood JCE, Giri DD. Nucleolar organizer regions as diagnostic discriminants for malignancy. $\mathscr{F}$ Pathol 1988;155: diagnos.

5 Derenzini M, Trere D. Importance of interphase nucleolar organizer regions in tumor pathology. Virchows Arch B Cell Pathol 1991;61:1-8.

6 Egan MJ, Crocker J. Nucleolar organiser regions in pathology. Br f Cancer 1992;65:1-7.

7 Mamaev NN, Medvedeva NV, Shust VF, et al. Nucleoli and AgNORs in Hodgkin's disease. 7 Clin Pathol Mol Patho 1997;50:149-52.

8 Lorand-Metze I, Carvalho MA, Metze K. Relationship between morphometric analysis of nucleolar organizer regions and cell proliferation in acute leukemias. Cytometry 1998;32:51-6.

9 Pich A, Chiusa L, Audisio E, et al. Nucleolar organizer region counts predict complete remission, remission duration, and survival in adult acute myelogenous leukemia patients. 7 Clin Oncol 1998;16:1512-18.

10 Korkolopoulou P, Angelopoulou MK, Kontopidou F, et al. Prognostic implications of proliferating cell nuclear antigen
(PCNA), AgNORs, and p53 in non-Hodgkin's lymphomas. Leuk Lymphoma 1998;30:625-36.

11 Kyle RA. Why better prognostic factors for multiple myeloma are needed. Blood 1994;83:1713-16.
12 Committee of the chronic leukemia-myeloma task force, National Cancer Institute. Proposed guidelines for protocol studies, II. Plasma cell myeloma. Cancer Chemother Rep 1973;4:145-58

13 Durie BGM, Salmon SE. A clinical staging system for multiple myeloma. Cancer 1975;36:842-54.

14 Morstyn G, Schechter GP, Ihde DC, et al. Therapy for multiple myeloma with alternating non-cross-resistant chemotherapy combinations: heterogeneity of tumor responsiveness. Cancer Treat Rep 1984;68:1439-46.

15 Crocker J, Nar P. Nucleolar organizer regions in lymphomas. f Pathol 1987;151:111-18.

16 Crocker J, Boldy DA, Egan MJ. How should we count AgNORs? Proposals for a standardized approach. F Pathol 1989;158:185-8.

17 Bartl R, Frisch B, Fateh-Moghamad A, et al. Histological classification and staging of multiple myeloma: a retrospective and prospective study of 674 cases. Am 7 Clin Pathol 1987;87:342-55.

18 Pich A, Marmont F, Chiusa L, et al. Argyrophilic nucleolar organizer region counts and prognosis in multiple myeloma. Br f Haematol 1992;82:681-8.

19 Pich A, Chiusa L, Marmont F, et al. Risk groups of myeloma patients by histologic pattern and proliferative activity. $\mathrm{Am}$ f Surg Pathol 1997;21:339-47.

20 Marmont F, Pich A, Chiusa L, et al. Correlation between argyrophilic nucleolar organizer region counts and labelling index in multiple myeloma. Eur f Haematol 1996;56: 39-44.

21 Skopelitou A, Tselenis S, Theocharis S, et al. Expression of proliferating cell nuclear antigen (PCNA) and nucleolar organizer regions (NORs) in multiple myeloma. Anticancer Res 1994:14:787-92.

22 Bryan RL, Janmohamed R, Crocker J, et al. Nucleolar organizer regions in myeloma and benign paraproteinaemia [letter]. Br F Cancer 1990;61:645.

23 Greipp PR, Kyle RA. Clinical, morphological, and cell kinetic differences among multiple myeloma, monoclonal gammopathy of undetermined significance, and smoldering multiple myeloma. Blood 1983;62:166-71.

24 Salmon SE. Immunoglobulin synthesis and tumor kinetics of multiple myeloma. Semin Hematol 1973;10:135-44.

25 Jandl HJ. Multiple myeloma and related plasma cell dyscrasias. In: Jandl HJ, ed. Blood: textbook of hematology, 2nd ed. Boston: Little, Brown and Co, 1996:1041-97.

26 Spielgelberg HL. Biological activities of immunoglobulins of different classes and subclasses. Adv Immunol 1974;19: 259-94.

27 Jozsa L, Kannus P, Jarvinen M, et al. Atrophy and regeneration of rat calf muscles cause reversible changes in the number of nucleolar organizer regions. Evidence that also in nonproliferating cells the number of NORs is a marker of protein synthesis activity. Lab Invest 1993;69:231-7.

28 Pollok A. Nucleolar organizer regions in exocrine pancreas in chronic pancreatitis and ductal adenocarcinoma. Diagnostic value and cytophysiologic correlate. Gen Diagn Pathol 1997;142:199-209.

29 Van Diest PJ, Brugal G, Baak JPA. Proliferation markers in tumours: interpretation and clinical value. $\mathcal{F}$ Clin Pathol 1998;51:716-24.

30 Mamaev NN, Mamaeva SE, Ushakova EA, et al. Results of the study of the activity of bone marrow nucleolar organizers in patients with multiple myeloma.[In Russian with English summary.] Tsitol Genet 1986;20:91-7.

31 Greipp R, Lust J, O'Fallon M, et al. Plasma cell labelling index and $\beta_{2}$-microglobulin predict survival independent of thymidine kinase and C-reactive protein in multiple myeloma. Blood 1993;81:3382-7. 